
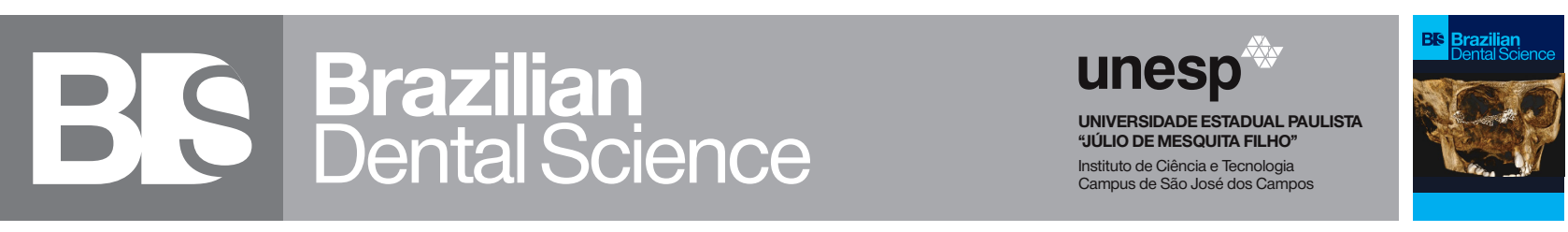

\title{
Clinical Performance of Direct Anterior Composite Restorations Using Esthetic Dual-Shade versus Polychromatic Natural Layering Technique: a split mouth randomized controlled clinical trial
}

Avaliação clínica do comportamento de desgaste do esmalte humano e lascamento da zircônia de cobrimento contra a zircônia monolítica (ensaio clínico randomizado controlado)

Ghada A ELZAYAT ${ }^{1}$, Mai M ELSAYED ${ }^{1}$, Amira F El ZOGHBY ${ }^{1}$

1 - Conservative dentistry department - Faculty of Dentistry - Cairo University - Cairo - Egypt.

\section{ABSTRACT}

Objective: to evaluate the clinical performance of the dual shade layering and polychromatic resin composite layering techniques using a randomized controlled trail. Material and Methods: 42 participants (84 restorations) of class IV or class III through and through within a pair of anterior contra-lateral teeth were randomly allocated into two groups according to technique of composite restoration placement: control "polychromatic layering" and intervention "dual-shade layering". Follow-up was done at 1 month (baseline) and 1 year. Restorations were evaluated using Visual Analog Scale (VAS), restoration color shade match using Vita Easyshade V ${ }^{\circledR}$, and blinded assessor using FDI criteria for assessment of dental restorations measuring (aesthetic properties). Chi-square test was used to compare between restorations of both techniques. Results: There was no statistically significant difference between restorations of both techniques for patient satisfaction outcome, restorations color match outcome, and for all tested FDI outcomes except surface luster with 100\% success. Conclusion: Both dual-shade layering and polychromatic natural layering techniques, exhibited acceptable clinical and esthetic performance.

\section{KEYWORDS}

Composite; Polychromatic layering technique; Dual-shade layering technique; Clinical performance.

\section{RESUIMO}

Objetivo: Avaliar o comportamento de desgaste do esmalte humano e lascamento de zircônia de cobrimento e monolítica para restaurações posteriores de cobertura total. Material e métodos: Trinta e quatro restaurações de zircônia de cobertura total (dezessete em cada grupo) foram fabricadas. Os pacientes foram divididos em dois grupos de acordo com o tipo de zircônia utilizada; grupo 1 (grupo comparador) coroas com zircônia de cobrimento e grupo 2 (grupo de intervenção) coroas únicas de zircônia monolítica. Todas as coroas foram fabricadas e polidas em laboratório. Para medidas de desgaste de dentes opostos, foi utilizado um perfilômetro 3D sem contato, onde réplicas de resina epóxi foram construídas para o arco oposto imediatamente após a cimentação das coroas, três, seis e doze meses. O lascamento da restauração foi medido usando critérios modificados dos Serviços de Saúde Pública dos Estados Unidos (USPHS). Resultados: Todas as restaurações foram relatadas como alfa sem lascamento. Não houve diferença estatisticamente significativa entre (Grupo 1) e (Grupo 2) para o teste de desgaste. Conclusão: As restaurações monolíticas e de cobrimento revelaram propriedades mecânicas satisfatórias sem lascamento após um ano de uso clínico. O desgaste do esmalte oposto foi clinicamente aceitável para ambos os materiais.

\section{PALAVRAS-CHAVE}

Cerâmica; Lascamento; Zircônia monolítica; Zircônia de cobrimento; Desgaste. 


\section{INTRODUCTION}

$\mathrm{R}$ esin composite materials are widely used to restore teeth for their good mechanical and aesthetic properties as well as relatively low-cost price. The clinical success of resin composites is related to their ability to reproduce tooth appearance in terms of gloss [1], micro texture $[2,3]$, and color [4].

The importance of external appearance and the cosmetic parameters dictated by modern society have led to an increase in esthetic demands. Additionally, the development of composite restoration materials has broadened their indication in the field of esthetic restorative procedures [5]. It is up to the operator, acting as an artist and scientist, to exploit the full potential of direct bonding and correlate them with natural tooth tissues to create better function and aesthetics without any bio-mechanical impairment and with constrained treatment time and costs [6].

In recent years, there is an increased attention to the color characteristics of the composites that are used for the reproduction of the structure of the teeth in conservative dentistry. In general, the tooth reproduction operation consists of two phases: the individuation of the color [7] and the selection of composite resin materials that will reproduce the chosen color [8]. According to that, restoring an anterior tooth has always been a challenge, regarding the shade matching, the choice of colors, opacities, translucencies of the composites and the final anatomical outcome.

Using one shade for small anterior class III or V restorations could be enough, while particularly challenging clinical situation involves class III through and through and class IV restorations, which have no backing tooth structure, and without an appropriate level of dentinal opacity, even the most ideal shade of composite may appear too grey, because the relatively translucent composite is unable to mask the dark background und of the oral cavity. Clinicians have devised "layering" techniques in which more translucent materials are placed over amore opaque composite in an effort to create depth from within the restoration [9].

Composite layering is often based on two different shades of the material, enamel and dentin, in different opacities and colors, with the goal to mimic the natural anatomy and appearance of the tooth. The restorative approach of layering, often called stratification, has been described as the "anatomic buildup technique" [10], the "trendy three-layer concept" [11]or the "natural layering concept" [2].

Using more shades is more time consuming and increases the number of possible combinations, thereby increasing the risk of choosing a potentially in correct combination. The layering of composite with different shades and translucencies is especially difficult because of the influence of thickness on the final shade and in choosing the right combination of colors [12].

Achieving restorations that are optimally aesthetic can be technique sensitive due to previous guidelines on building complex layered composite restorations with suggestion to mix several shades and materials of varying consistency [13]. Dentists commonly report that such techniques are time consuming, complicated, and don't offer predictability in terms of aesthetics. Therefore, the direct composite placement technique become overwhelming, time consuming, and very important factor in the restoration success [14].

Due to lack of randomized control trails and limited evidence-based information in literature which may help the practitioners to choose between different layering techniques, in order to provide a restoration achieving patient satisfaction, fulfill shade match with the remaining tooth structure and with good clinical performance. It was found beneficial to evaluate the clinical performance of the dual shade layering and polychromatic resin composite layering techniques using a randomized controlled trail.to test the null hypothesis that dual shade layering technique capable 
of providing a highly esthetic and durable restoration compared to polychromatic natural layering technique.

\section{MATERIALS AND METHODS}

\section{Study Design}

In a randomized controlled split mouth design, 42 participants (84 restorations) of class IV or class III through and through within a pair of anterior contra-lateral teeth were randomly allocated by selecting a sealed envelope containing which half received either the (treatment 1) control; polychromatic layering or other (treatment 2) intervention; dual-shade layering. Materials were applied according to the manufacturers' instructions.

Follow-up was done at 1 month (baseline) and 1 year. Restorations were evaluated using Visual Analog Scale (VAS), restoration color shade match using Vita Easyshade V $®$, and blinded assessor using FDI criteria for assessment of dental restorations measuring (aesthetic properties).This trial was approved by standards of Research Ethics Committee of Faculty of Dentistry, Cairo University(CREC) and registered in (www.clinicaltrials.gov/) database, with unique identification number NCT02999880.This trial was conducted following the Consolidated Standards of Reporting Trials (CONSORT) Statement to improve reports on randomized controlled trials (RCT) reference.

\section{Patient Selection}

The Study took place at the outpatient clinic of Conservative Dentistry department in Faculty of Dentistry, Cairo University. Participants were recruited to fulfill the eligibility criteria summarized in Table I. All participants signed written informed consents after being completely aware of the aim, settings, procedures, benefits and potential side effects of the study. The study information and consent forms were written in Arabic language to be well understood by all the participants.
Table I - Inclusion and exclusion criteria.

\begin{tabular}{|c|c|}
\hline Inclusion Criteria & Exclusion Criteria \\
\hline \multicolumn{2}{|c|}{ Patient-related criteria } \\
\hline $\begin{array}{l}\text {-Patients with good general } \\
\text { health. } \\
\text { - Patients who agreed to the con- } \\
\text { sent and committed to follow-up } \\
\text { period } \\
\text { - No specific age range. } \\
\text { - Both genders. }\end{array}$ & $\begin{array}{l}\text { - Patient with bad oral hygiene. } \\
\text { - Patients with tetracycline or } \\
\text { fluorosis staining. } \\
\text { - Patients who could/would not } \\
\text { participate in all times of follow-up. } \\
\text { - Patients participating in more } \\
\text { than 1dental study. } \\
\text { - Patient received fluoride varnish, } \\
\text { or during orthodontic treatment. } \\
\text { - Patients with tendency to do } \\
\text { bleaching during the study. }\end{array}$ \\
\hline \multicolumn{2}{|c|}{ Tooth-related criteria } \\
\hline $\begin{array}{l}\text { - Fully erupted permanent anterior } \\
\text { teeth with bilateral class III through } \\
\text { and through or class IV. } \\
\text { - Active caries, fractures, or defec- } \\
\text { tive Restorations in anterior teeth. }\end{array}$ & $\begin{array}{l}\text { - Untreated periodontal disease } \\
\text { was not allowed. } \\
\text { - Fully erupted anterior teeth with } \\
\text { no defects. }\end{array}$ \\
\hline
\end{tabular}

\section{Sample Size}

If there was truly no difference between the standard and experimental treatment, then(42 patients) 84 restorations were required to be $80 \%$ sure that the limits of a two-sided $95 \%$ confidence interval would exclude a difference between the standard and experimental group of more than $10 \%[15,16]$.

\section{Pre-operative Assessment}

1-Patient diagnostic assessment chart was filled.

2- Standard preoperative digital photographs were taken by canon 6D DSLR

3- After prophylaxis with prophylactic paste and a nylon brush, the shade determination was performed with Vita Easyshade Base shade determination mood (Figure 1). 


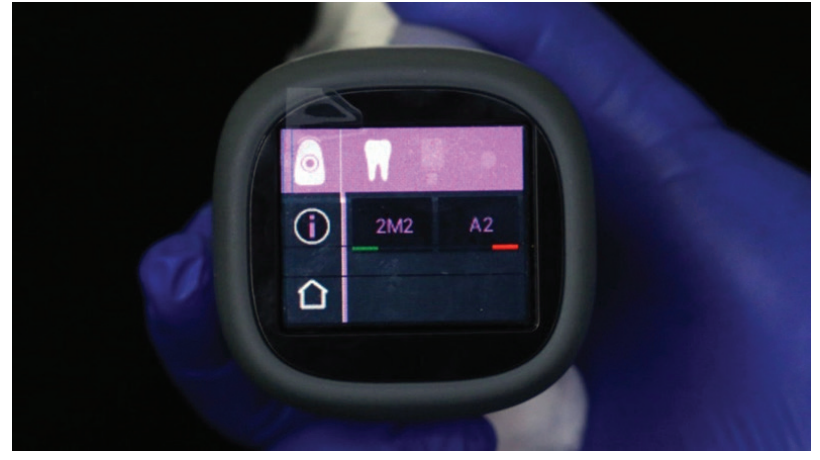

Figure 1 - Teeth shade determination mood using Vita Easy shade.

\section{Operative procedure}

Fabricating a silicon index: silicone matrix (ZETAPLUS, Zhermack S.p.A.) was fabricated either directly in the patient mouth using lingual surface of the remaining tooth structure and the existing restorations as a guide, or fabricated on a study cast after optimizing the shape and function of the teeth with a wax up.

Teeth preparation: After local anesthesia and rubber dam isolation was achieved, and a floss ligature was used to displace the rubber damapically. A (approx1.5-mm) 75-degree functional esthetic enamel bevel [17]was prepared using a fine grained finishing diamond rotary instrument (8888.31.012; Brasseler USA) on the facial surface, the bevel enables harmonious shade transition from composite to tooth substance.

\section{Restorative Procedure}

Application of adhesive system (Scotchbond Universal Etchant and Adper Single Bond 2 Adhesive) Scotchbond Universal Etchant was applied through the tip of the syringe, enamel and dentin surfaces were treated with the etchant for 30 and 15 seconds, respectively. Then it was rinsed with copious water irrigation for 30 seconds and the excess water was removed with cotton pellets. Thin layer of the adhesive was applied afterwards and rubbed against the tooth structure with pressure for 20 seconds using brush. Adhesive was then air thinned using gentle air stream for 5 seconds, and finally photo-cured for 20 seconds according to the manufacturer's recommendations using LED light curing unit (Figure 2).

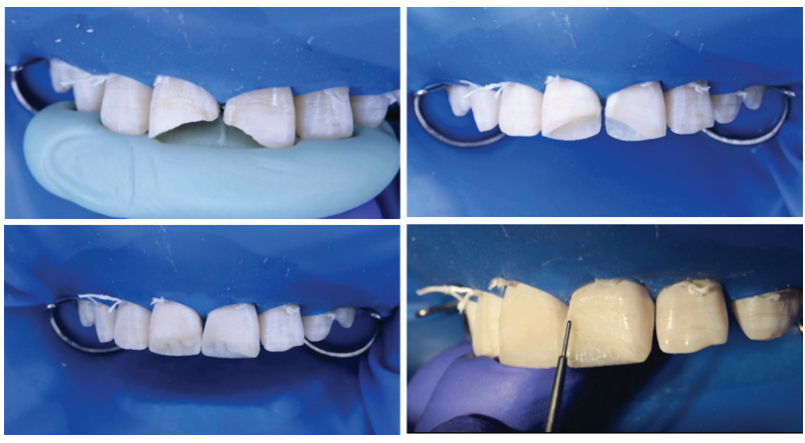

Figure 2 - Representatives images for restorative procedures.

Dual-shade layering (Intervention): The silicon matrix was positioned followed by application of the palatal thin layer of composite (Filtek $^{\mathrm{Tm}}$ Z350 XT Universal Restorative) with the selected body shade to reproduce the palatal portion of the tooth and after photo-curing for 20 seconds the silicone matrix was removed. A thin convex posterior matrix (Garrison Dental) was placed in a vertical position to create a natural and anatomic surface and to restore the interproximal walls and contacts. Using the same body shade thickness was added to the palatal portion to form the dentin aspect of the restoration. A final other body shade composite (one shade lighter) was selected for the facial enamel aspect of the restoration.

Polychromatic layering (Comparator): The silicon matrix was positioned followed by application of the palatal thin layer of composite (Filtek $^{\mathrm{TM}}$ Z350 XT Universal Restorative)with the translucent shade to form the palatal portion and after photo-curing for 20 seconds using LED light curing unit the silicone matrix then was removed. A thin convex posterior matrix was placed in a vertical position to create a natural and anatomic surface. and to restore the interproximal walls and contacts. The selected dentin shade composite (Filtek $^{\mathrm{TM}}$ Z350 XT Universal Restorative) was applied and photo-cured to reproduce the dentin tissues with build-up of mamelons in the incisal third then placement of translucent enamel to accentuate the recreated dentine mamelons and maximize translucency of the incisal edge.Misura hand instrument (Misura, LM Arte, Finland) was used to calibrate the dentin and leave a 0.5- 
$\mathrm{mm}$ space for the labial enamel placement. An overlying layer of previously selected enamel shade composite was placed (Filtek ${ }^{\mathrm{TM}}$ Z350 XT Universal Restorative). Finally, a very thin layer of translucent composite was added over the surface of the restoration to take advantage of their gloss and excellent polish retention.

Finishing and polishing were performed for the anatomical contouring and smoothing of the labial and palatal surfaces using all grates of soflex discs (sof-lex, 3M ESPE), fine and Extra fine diamond burs (Brasseler), finishing strips, medium and fine rubber polishing points(Jiffy Polishers, Ultradent)

\section{Satisfaction Assessment (VAS scale):}

At first, patient was asked for his satisfaction by visual analogue scale $(0-100 \mathrm{~mm}), 0$ score refer to not satisfied at all, while 100 score refer to totally satisfied. The evaluation was done separately for left and right teeth. By instructing to lookinto a mirror and evaluate each tooth alone then patient rated his satisfaction by making a vertical mark on the $100-\mathrm{mm}$ line. The measurement in millimeters was transformed to the same number of points ranging from 0 to 100 points. The exact question was "What is your degree of satisfaction at present?" [18].The patient was educated for repeating the same test after treatment and ended in the follow up period.

\section{Easy shade: \\ Verification of the shade match using Vita}

To Verify the shade of a restoration, both the intervention and the comparator were assessed using intraoral spectrophotometer, Vita Easyshade $\mathrm{V}^{\circledR}$, for both baseline record and one-year record.

The extent of the match (restoration target shade) is symbolized by red /yellow / green, as shown in the following illustrations:

- RED means "Adjust." This means that there is a recognizable difference between the base shade of the restoration and the target shade it was compared to. The restoration must be reworked to achieve an acceptable shade match.

- YELLOW means "Average." This means that there is a recognizable but still acceptable difference between the base shade of the restoration and the target shade it was compared to.

- GREEN means "Good." This means that there is little or no difference between the base shade of the restoration and the target shade that it was compared to.

\section{Clinical evaluation using FDI criteria:}

FDI Esthetic properties criteria selected for assessment are presented in Table II. [19].

Table II - FDI Esthetic properties criteria selected for assessment.

\begin{tabular}{|c|c|c|c|c|}
\hline $\begin{array}{l}\text { A. Esthetic } \\
\text { properties }\end{array}$ & $\begin{array}{l}\text { 1. Surface } \\
\text { luster }\end{array}$ & $\begin{array}{l}\text { 2. Surface } \\
\text { staining }\end{array}$ & $\begin{array}{l}\text { 3. Color } \\
\text { matchand } \\
\text { translu- } \\
\text { cency }\end{array}$ & $\begin{array}{c}4 . \\
\text { Anatomic } \\
\text { form }\end{array}$ \\
\hline $\begin{array}{l}\text { 1. Clinically } \\
\text { excellent/ } \\
\text { Very good }\end{array}$ & $\begin{array}{l}\text { 1.1 Luster } \\
\text { comparable } \\
\text { to enamel }\end{array}$ & $\begin{array}{l}\text { 2.1No surfa- } \\
\text { ce staining }\end{array}$ & $\begin{array}{l}\text { 3.1Good color } \\
\text { match No } \\
\text { difference in } \\
\text { shade and } \\
\text { translucency }\end{array}$ & $\begin{array}{l}\text { 4.1Form is } \\
\text { ideal }\end{array}$ \\
\hline $\begin{array}{l}\text { 2.Clinically } \\
\text { good (after } \\
\text { polishing } \\
\text { very good) }\end{array}$ & $\begin{array}{l}\text { 1.2 Slightly } \\
\text { dull, not noti- } \\
\text { ceable from } \\
\text { speaking } \\
\text { distance }\end{array}$ & $\begin{array}{l}\text { 2.2 Minor } \\
\text { staining, } \\
\text { easily remo- } \\
\text { vable }\end{array}$ & $\begin{array}{l}\text { 3.2 Minor } \\
\text { deviations }\end{array}$ & $\begin{array}{l}4.2 \text { Form is } \\
\text { only affected }\end{array}$ \\
\hline $\begin{array}{l}\text { 3. Clinically } \\
\text { sufficient/ } \\
\text { satisfactory } \\
\text { Minor } \\
\text { (shortco- } \\
\text { mings, no } \\
\text { unaccepta- } \\
\text { ble effects } \\
\text { but not } \\
\text { adjustable } \\
\text { w/o dama- } \\
\text { ge to the } \\
\text { tooth) }\end{array}$ & $\begin{array}{c}\text { 1.3Dull } \\
\text { surface but } \\
\text { acceptable if } \\
\text { covered with } \\
\text { film of saliva }\end{array}$ & $\begin{array}{l}2.3 \text { staining, } \\
\text { also present } \\
\text { Moderate } \\
\text { surface on } \\
\text { other teeth, } \\
\text { not estheti- } \\
\text { cally unac- } \\
\text { ceptable }\end{array}$ & $\begin{array}{c}\text { 3.3 Clear } \\
\text { deviation but } \\
\text { acceptable. } \\
\text { Does not } \\
\text { affect esthe- } \\
\text { tics: } \\
\text { 3.3.1 more } \\
\text { opaque } \\
\text { 3.3.2 more } \\
\text { translucent } \\
\text { 3.3.3 darker } \\
\text { 3.3.4 brighter }\end{array}$ & $\begin{array}{l}\text { 4.3Form } \\
\text { differs } \\
\text { but is not } \\
\text { esthetically } \\
\text { displeasing }\end{array}$ \\
\hline $\begin{array}{c}\text { 4.Clinically } \\
\text { unsatisfac- } \\
\text { tory (but } \\
\text { reparable) }\end{array}$ & $\begin{array}{c}1.4 \text { Rough } \\
\text { surface, } 1.4 \\
\text { Rough surfa- } \\
\text { ce, by saliva } \\
\text { film, simple } \\
\text { polishing } \\
\text { is not suffi- } \\
\text { cient. Further } \\
\text { intervention } \\
\text { necessary }\end{array}$ & $\begin{array}{l}\text { 2.4 Surface } \\
\text { staining } \\
\text { restoration } \\
\text { and is } \\
\text { present on } \\
\text { the unaccep- } \\
\text { table; major } \\
\text { intervention } \\
\text { necessary } \\
\text { for improve- } \\
\text { ment }\end{array}$ & $\begin{array}{l}\text { 3.4 (Localized) } \\
\text { clinically } \\
\text { unsatisfac- } \\
\text { tory but can } \\
\text { be corrected } \\
\text { by repair; } \\
\text { 3.4.1 too opa- } \\
\text { que } 3.4 .2 \text { too } \\
\text { translucent } \\
3.4 .3 \text { too dark } \\
3.4 .4 \text { too } \\
\text { bright }\end{array}$ & $\begin{array}{l}\text { 4.4. Form } \\
\text { is affected } \\
\text { and unac- } \\
\text { ceptable } \\
\text { esthetically. } \\
\text { Intervention } \\
\text { (correction) } \\
\text { necessary }\end{array}$ \\
\hline $\begin{array}{l}\text { 5. Clinically } \\
\text { poor (re- } \\
\text { placement } \\
\text { necessary) }\end{array}$ & $\begin{array}{l}1.5 \text { Quite } \\
\text { rough } \\
\text { unaccepta- } \\
\text { ble plaque } \\
\text { retentive } \\
\text { surface }\end{array}$ & $\begin{array}{l}2.5 \text { Severe } \\
\text { staining and/ } \\
\text { or subsurfa- } \\
\text { ce staining } \\
\text { (generalized } \\
\text { or localized); } \\
\text { not accessi- } \\
\text { ble for inter- } \\
\text { vention) }\end{array}$ & $\begin{array}{c}\text { 3.5Unac- } \\
\text { ceptable } \\
\text { Replacement } \\
\text { necessary }\end{array}$ & $\begin{array}{l}4.5 \text { Form is } \\
\text { completely } \\
\text { unsatisfac- } \\
\text { tory and/or } \\
\text { lost. Repair } \\
\text { not feasible/ } \\
\text { reasonable, } \\
\text { replacement } \\
\text { needed }\end{array}$ \\
\hline
\end{tabular}




\section{Data collection and follow-up examination}

Base line data collection was done by (O.S) who took the medical and dental history for every patient. Also, filled examination charts (Patient information- medical history- dental history - chief complaint.

Outcome data collection: (M.M) and (G.Z) recorded all the outcomes results at the following times: before, one month after, 1 year.

\section{blinding}

Sequence generation, allocation and

Patients were enrolled with minimum two contra-lateral anterior. Teeth were divided into two groups: 42 For intervention (Dualshade layering) and other:42 For control (Polychromatic layering), that every patient received both. (R) Represent the right side or (L) represents the left side. Using coin tossing method, the patient may have (R Polychromatic layering, L Dual-shade layering) or (L Polychromatic layering, R Dual-shade layering).

Participants were randomized to ensure the allocation concealment, by preparing opaque sealed envelopes containing the grouping generated previously and titled by numbers as the randomization codes were not released until the patients had been recruited into the trail, which took place after all baseline measurement had been completed.

The operator was not blinded to technique assignment because of the difference in the application technique of the restorative material, which prohibited blinding of the operator; however, assessor and the statistician were blinded to the technique assignment.

\section{Statistical analysis}

Chi-square test was used to compare between restorations of both techniques: intervention (dual-shade layering), and control (polychromatic layering) at the base line and after one year. A p-value $\leq 0.05$ was considered statistically significant.
All data were collected, tabulated and statistically analyzed after testing it with normality test by SPSS ${ }^{\circledR} 20$, excel $2018{ }^{\circledR}$ grap g pad prism.

\section{RESULTS}

\section{Clinical Evaluation Using FDI Criteria:}

\subsection{Surface Luster:}

Comparison between Dual Shade and Polychromatic groups was performed using Chi Square test for each score at different follow up periods. It was revealed that there was significant difference between both groups for each score as P-value $<0.05$. (Figure 3 )

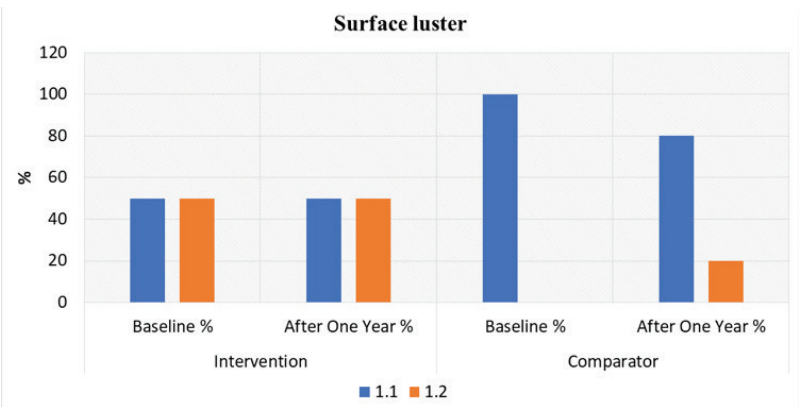

Figure 3 - Bar chart showing surface luster outcome comparison (baseline and after 1 year) between Intervention (dual-shade) and Comparator (polychromatic).

\subsection{Surface staining, Anatomic Form} and Translucency:

Comparison between Dual Shade and Polychromatic groups was performed using Chi Square test for each score at different follow up periods. It was revealed that there was absolute insignificant difference between both groups as P-value $>0.05$. (Figure 4) 

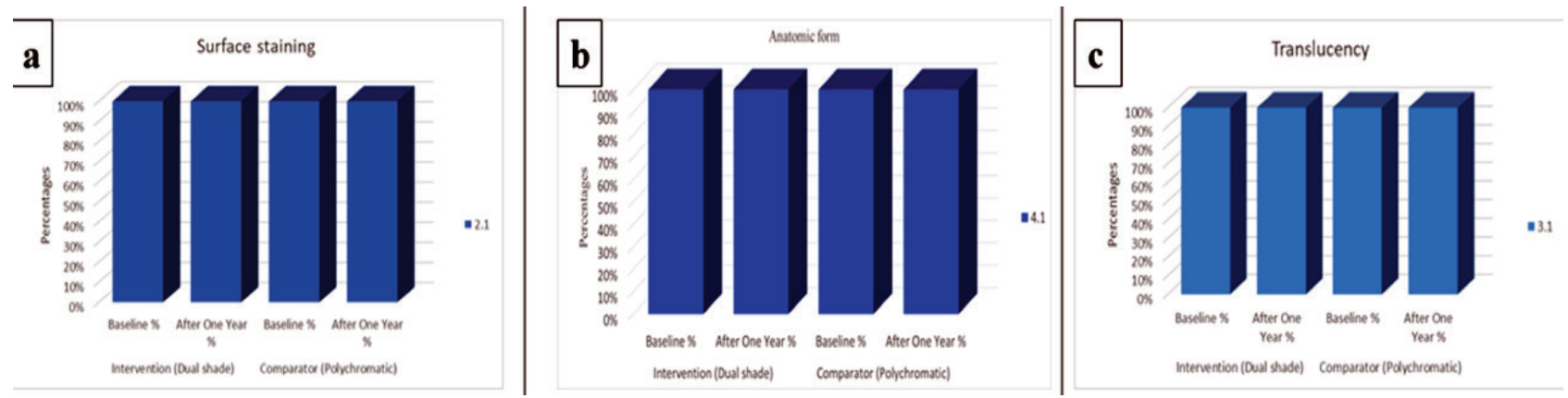

Figure 4 - Bar chart showinganatomic form outcome comparison (baseline and after 1 year) between Intervention(dual-shade) and Comparator (polychromatic).

\section{Color Shade match evaluation Using} Easy Shade ${ }^{\circledR}$ :

Comparison between the two tested groups was performed using Chi Square test for each score at different follow up periods concerning color shade match. It was revealed that there was insignificant difference between both groups for each score as P-value $>0.05$ (Figure 5)

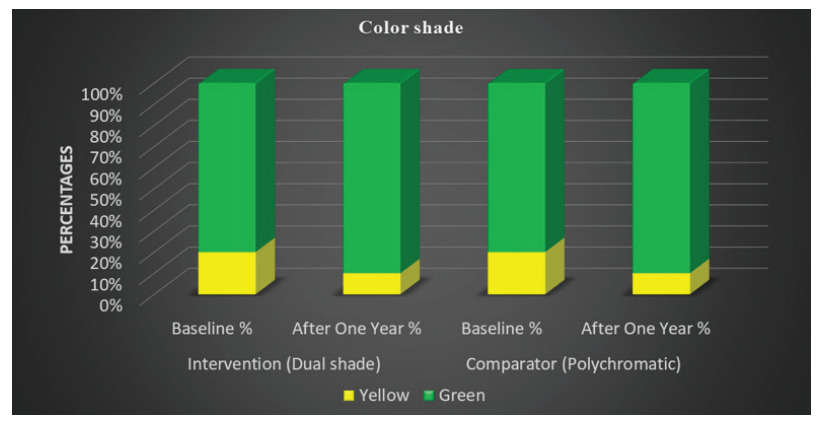

Figure 5 - Bar chart showingcolor shade outcome comparison (baseline and after 1 year) between Intervention(dual-shade) and Comparator (polychromatic).

\section{Patient Satisfaction Assessment Using Visual Analogue Scale (VAS):}

Regarding assessment of patient satisfaction using visual analogue scale (VAS), ranged from (0) to (100) for Dual Shade and Polychromatic groups along one year follow up period.

For Dual Shade group, patient satisfaction revealed (94\%) and (93\%) for baseline and after one year respectively. While for Polychromatic group, patient satisfaction revealed (97\%) and (95\%) for baseline and after one year respectively, (table 19 and figure 42).

Using one-way analysis of variance (One Way ANOVA) followed by Tukey`s post hoc test for multiple comparisons, it was revealed that there was insignificant difference between both groups for all follow up periods as P-value $>$ 0.05 (Figure 6)

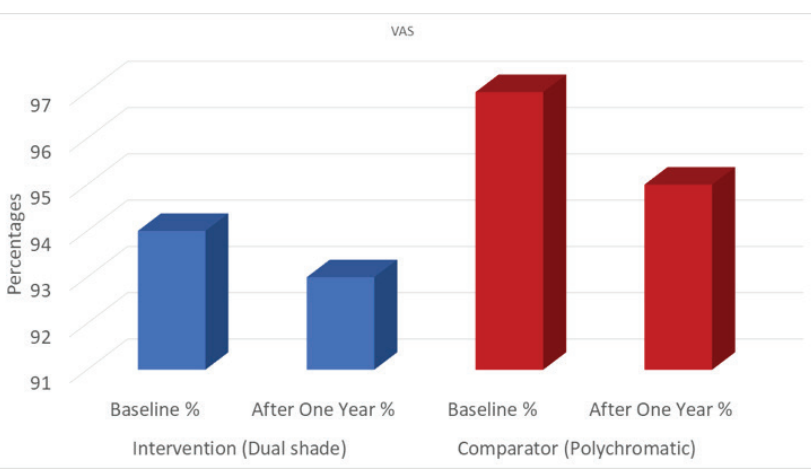

Figure 6 - Bar chart showingVAS outcome comparison (baseline and after 1 year) between Intervention (dual-shade) and Comparator (polychromatic).

\section{4. photograph assessment}

Standard post-operative digital photographs were taken by canon 6D DSLR (Digital Single Lens Reflex) with 100 macro 2.8. (focal lens) for post-operative and follow up documentation (Figure 7). 


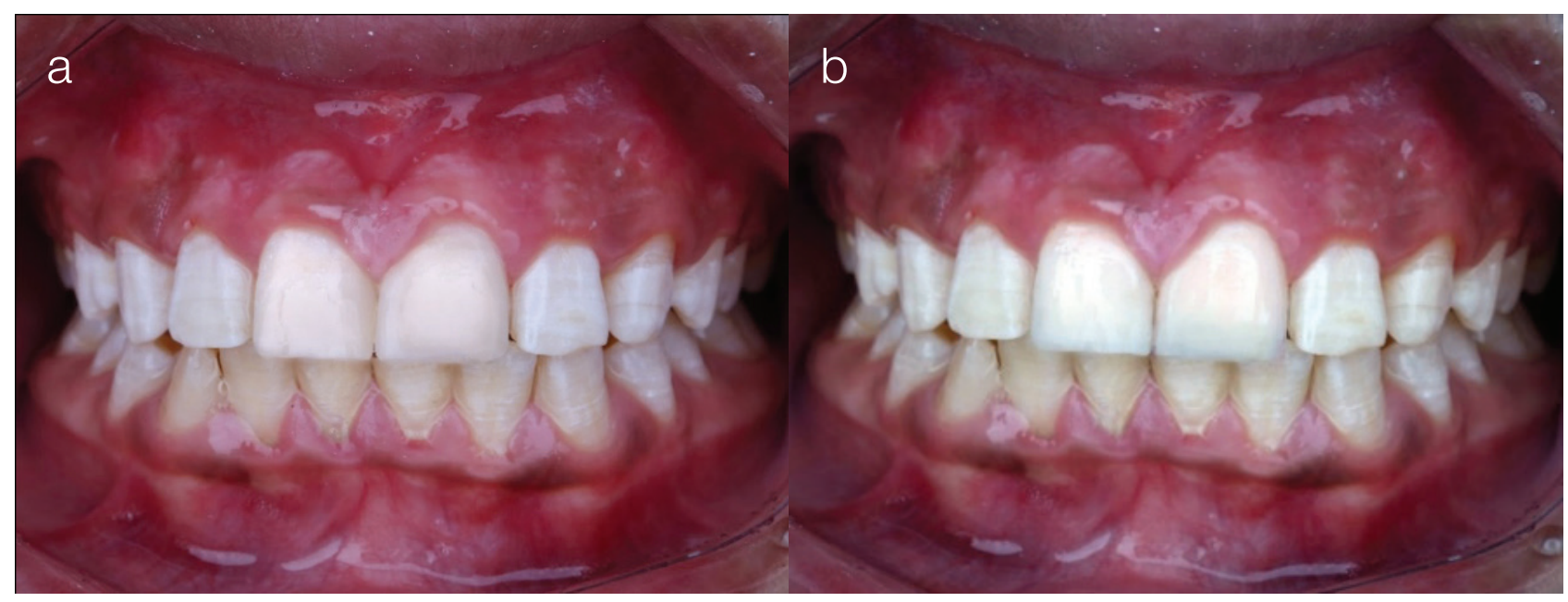

Figure 7 - A photographic image showing the final result for the layering techniques, a- immediately post-operative; b- 1-year assessment

\section{DISCUSSION}

Nanocomposites have physical and mechanical properties approximating to tooth structure for achieving clinical success, as superior mechanical resistance to fracture and wear, lower polymerization shrinkage, excellent polishing, color stability, and good optical properties such as fluorescence and translucency, and are safely recommended for restorations of anterior and posterior teeth [20]. On the other hand, human teeth are multilayered structures composed of dentin and enamel that had different optical characteristics. The tooth color is associated with the light scattering and absorption properties of the enamel and dentin [21].

In the current study the nanocomposite Filtek Z350XT was used with different shades and opacities. It is composed of silica nanoparticles and silane-coated zirconia prior to incorporation into the resin matrix (manufacturer's technical product profile).Due to the small-sized filler particles, a larger amount can be inserted into the resin matrix, providing excellent physical and mechanical properties of the material. Also, it has a wider range of shades in all opacities, dentin, enamel, body and translucent which provides the ability of using it in a single, dual or multi-shade technique.
The percentage of light transmission on the enamel is approximately $70.1 \%$, which provides translucent characteristics to this tissue. In contrast, the percentage on the dentin is $52.6 \%$, which makes it more opaque [7]. In order to obtain natural characteristics, more transparent resins should be used in the fabrication of artificial enamel, whereas more opaque resins should be used to reproduce artificial dentin.

The incremental approach allows the perfect masking between tooth and restoration reproducing more accurately the optical and physical-mechanical characteristics of each dental substrate [22].

In this current study, the polychromatic natural layering technique (comparator) was used because it's ability to reproduce the natural stratification of the teeth [5].

Wide clinical experience has demonstrated that different thicknesses of composite can affect or benefit the restoration, this meaning that with only one dentin and one enamel we can obtain many different colors, making our restorative treatment unpredictable and dangerous in terms of integration [23].A special hand instrument (Misura, LM Arte,Finland) was used to calibrate a perfect $0.5 \mathrm{~mm}$ thickness for reproduction of buccal enamel with the selected shade of the enamel composite [23]. 
The use of different shades and opacities of composite in this technique, in a special order and predefined thickness for the labial enamel layer, is the fundamental principle of polychromatic layering technique in order to replicate the layers seen in natural teeth. Polychromatic technique, though somewhat technique-sensitive, time consuming and can work wonders in emulating natural dentition and satisfying the patient's cosmetic anticipations [24].

Randomized controlled trials (RCTs), systematic reviews and meta-analyses are placed at the pyramid's top, representing the highest level of available evidence and assessing the actual clinical performance of the restorations $[25,26]$.This clinical study was randomized and used a split-mouth design to eliminate any bias due to patient variables [27].

Concerning cavity configuration, the most challenging is the class IV and large class III through and through which have no backing tooth structure. A relatively translucent composite may not be able to mask the dark background of the oral cavity and only one shade may not be able to color match with the remaining tooth structure $[28,29]$

A functional esthetic enamel bevel, was prepared in this study for achieving less marginal microleakage, better adhesion, lower risk of enamel marginal fracture and better transition between composite resin and dental substrate, which inducing higher esthetic pattern [30].

Two step total etch adhesive system was used instead of self-etching adhesives, which are not recommended when restoring cavities that lack sufficient resistance and retention form (e.g. Class IV), as they contain weaker acids that will not sufficiently penetrate enamel to a depth that maximizes resin-tag formation [31].

Proper contouring, finishing and polishing steps were done using appropriate sequenced protocol. This is due to the importance of this step for the accomplishment of resin composite anterior restorations as a key component to the long-term success of bonded restorations [32], and its direct effect on the final esthetic outcome of the restorations in the study.

The patient viewpoint is an important factor that drive the demanding for the dental treatment. It is a subjective method for assessment, but patient satisfaction score is important as it gives an indication about patient esthetic demands and the degree of improvement by treatment and ensures that one of the research outcome is patient relevant [33].

Color assessment was done using spectrophotometer which considered one of the high qualities and clinical reliable for color change [34,35].

For the clinical assessment of dental restorations, modified United States Public Health Service (USPHS) criteria and FDI criteria are the most used [36], had developed a more sensitive, discriminative practical, relevant, and standardized scale than the modified USPHS criteria based on three criteria categories: aesthetic, functional and biological. Since then the percentage of studies using FDI criteria increased from $4.5 \%$ in 2010 to $50.0 \%$ in 2016 , with surface luster, surface staining and color match considered of the most employed criteria regarding aesthetic evaluation [37].

In the present study, esthetics properties were the only selected criteria for assessment, as the restorations placed in a visible area like anterior teeth. The functional and biological properties can be dropped, as functional and biological issues are of low interest compared to esthetics [19].

According to the results obtained from the current study, after one year all restorations were evaluated with no dropouts, the retention rate was $100 \%$. Restorations constructed using dual shade technique (intervention), have shown clinical performance nearly like those constructed using polychromatic technique (comparator) after one year of clinical service; therefore, the null hypothesis was accepted.

Despite the inherent subjectivity in valuing aesthetic outcomes of direct anterior resin composite restorations, most studies have been 
focused on biological and mechanical behavior of the composite restorations and ignored the perceptions of patients [33]. For this reason, the study might provide a more reasonable scenario for the assessment of the performance of restorations constructed using dual shade and polychromatic techniques concerning aesthetic and satisfaction. Regarding the visual analogue scale(VAS) scale it was found that, there was insignificant difference between restorations constructed using dual shade and polychromatic layering in both follow up periods. This gives us a good point for qualitative comparison of both techniques' behavior toward satisfaction.

Clinical evaluation according to FDI criteria of surface staining, color match and translucency, anatomic form for polychromatic technique scored as clinically excellent for all the restorations at baseline, and after one year with absolute insignificant differences between the restorations over time. With respect to surface luster, there were significant differences between different follow up periods for each score as $(\mathrm{P}<0.05)$. This may be due to applying a final layer of translucent composite with less filler loading than that used for other shades. In terms of filler loading and nanofiller particle sizes, translucent resin composites represent lower filler content [38]. The reduced filler loading in resin composite provided resiliency and minimized polymerization shrinkage stresses, yet this impaired the gloss and wear resistance of the composite during function [32]. Moreover, the higher matrix content increased water sorption and solubility which affected long term performance of the resin composite [39].

Concerningsurface luster, only the presence of significant difference between both groups was obtained. This can distinctly explained by applying a final very thin layer of clear translucent resin on the restorations constructed by polychromatic technique, which provide advantage of their excellent polish retention and subsequently increase surface luster as the manufacturer's claimed.
In terms of color match and translucency, the results showed that polychromatic natural layering technique (comparator) which is assumed as gold standard [5],was capable of providing a highly aesthetic anterior resin composite restoration with good color match and this was in accordance with [23,40,41] However, according to the current results, it was found that dual shade technique could also provide a highly aesthetic anterior resin composite restoration with good color match, as there was absolute insignificant difference between both groups concerning color match and translucency and this was in accordance with [28].

Regarding color shade match evaluation using Vita Easy Shade ${ }^{\circledR}$ both dual shade group and polychromatic group restorations, scored either (green) little or no difference between restoration shade and the target shade it was compared to, or (yellow) recognizable but still acceptable difference between restoration shade and the target shade it was compared to, at baseline and after one year, with no statistically significant difference between both groups over time.

Vita Easy Shade ${ }^{\circledR}$, is one of the high qualities and reliable available clinical spectrophotometers [42].It was recommended to use both instrumental and visual color matching method whenever possible as they complement each other and can lead towards predictable esthetic outcome [43]. Our results concerning clinical evaluation of the restorations color match and translusency using FDI criteria, match the results using Vita Easy Shade ${ }^{\circledR}$ with no statistically significant difference between both dual shade and polychromatic groups over time. That is why it was advised by [44] for best practice to use both human assessment and digital evaluation to ensure that acceptable aesthetics are achieved.

\section{CONCLUSION}

Both dual-shade layering and polychromatic natural layering presented 
acceptable clinical and esthetic performance in anterior restoration especially class IV cavities. The simpler dual-shade technique may provide a successful alternative for the polychromatic technique.

\section{REFERENCES}

1. Ardu S, Braut V, Uhac I,Benbachir N, Feilzer AJ, Krejci I. Influence of mechanical and chemical degradation on surface gloss of resin composite materials. Am J Dent 20090ct:22(5):264-8.

2. Ardu S, Krejci l. Biomimetic direct composite stratification technique for the restoration of anterior teeth. Quintessence Int. 2006 Mar;37(3):167-74.

3. Heintze SD, Forjanic M, Rousson V.Surface roughness and gloss of dental materials as a function of force and polishing time in vitro. Dent Mater. 2006;22(2):146-65. doi:10.1016/.dental.2005.04.013

4. Chu SJ, Devigus A, Mieleszko AJ. Fundamentals of color: shade matching and communication in esthetic dentistry. Illinois: Quintessence Publishing Company;2004

5. Betrisey E, Krejcil, Di BellaE, Ardu S. The influence of stratification on color and appearance of resin composites. Odontology.2016;104(2):176-83. doi:10.1007/ s10266-015-0197-2

6. Dietschi D, Fahl $\mathrm{N}$ Jr.Shading concepts and layering techniques to master direct anterior composite restorations: an update. Br Dent J. 2016;221(12):76571. doi:10.1038/sj.bdj.2016.944

7. Nahsan FPS, Mondelli RFL,Franco EB, Naufel FS, Ueda JK, SchmittVL, et al. Clinical strategies for esthetic excellence in anterior tooth restorations: understanding color and composite resin selection. J Appl Oral Sci. 2012:20(2):151-6. doi:10.1590/s1678-77572012000200005

8. Gueli AM, Pedullà E, Pasquale S, La Rosa GR, Rapisarda E. Color specification of two new resin composites and influence of stratification on their chromatic perception. Color Res Appl. 2017;42(5):684-92.

9. RyanE-A, Tam LE, McComb D. Comparative translucency of esthetic composite resin restorative materials. J Can Dent Assoc. 2010;76:a84.

10. Vanini L. Light and color in anterior composite restorations. Pract Periodontics AesthetDent. 1996;8(7):673-84.

11. FahI $\mathrm{N}$ Jr. Achieving ultimate anterior esthetics with a new microhybrid composite. Compend Contin Educ Dent Suppl. 2000;(26):4-26.

12. Østervemb N, Jørgensen JN, Hørsted-Bindslev P. A new approach to compare the esthetic properties of different composite materials. J Esthet Restor Dent. 2011;23(4):238-46. doi:10.1111/1.1708-8240.2010.00398.x

13. Beddis HP,Nixon PJ. Layering composites for ultimate aesthetics in direct restorations. Dent Update.2012;39(9):630-6. doi:10.12968/denu.2012.39.9.630

14. Milnar FJ. Achieving natural aesthetics in Class IV restorations. Dent Today. 2012;31(1):144-6.

15. Peumans M, Van Meerbeek B, Lambrechts P,Vanherle G. The 5-year clinical performance of direct composite additions to correct tooth form and position Clin Oral Investig. 1997;(1):12-8.

16. Julious SA. Sample sizes for clinical trials. Boca Raton: Chapman and Hall/ CRC;2009.
17. Vargas M. Conservative aesthetic enhancement of the anterior dentition using a predictable direct resin protocol. Pract Proced Aesthet Dent. 2006;18(8):501-7.

18. Ishida Y, Fujimoto K, Higaki N, Goto T, Ichikawa T.End points and assessments in esthetic dental treatment.JProsthodont Res. 2015;59(4):229-35. doi:10.1016/.jpor.2015.05.002

19. Hickel R, Peschke A, Tyas M, Mjör I, Bayne S, Peters M, etal.FDI World Dental Federation: clinical criteria for the evaluation of direct and indirect restorations-update and clinical examples. Clin Oral Investig. 2010;14(4):34966. doi:10.1007/s00784-010-0432-8

20. Curtis AR, Palin WM, Fleming GJ, Shortall AC, Marquis PM. The mechanical properties of nanofilled resin-based composites: the impact of dry and wet cyclic pre-loading on bi-axial flexure strength. Dent Mater. 2009;25(2):188-97. doi:10.1016/.jental.2008.06.003

21. Ten Bosch JJ, Coops JC. Tooth color and reflectance as related to light scattering and enamel hardness. J Dent Res. 1995;74(1):374-80. doi:10.1177/00 220345950740011401

22. BaratieriLN, Araujo E, Monteiro S Jr. Color in natural teeth and directresin composite restorations: essential aspects. Eur JEsthet Dent. 2007;2(2):172-86.

23. Manauta J, Salat A, Putignano A, Devoto W, Paolone G, Hardan LS. Stratification in anterior teeth using one dentine shade and a predefined thickness of enamel: a new concept in composite layering--Part I. Odontostomatol Trop. 2014;37(146):5-16.

24. FahI N Jr. A polychromatic composite layering approach for solving a complex Class IV/direct veneer-diastema combination: partl. Pract Proced Aesthet Dent. 2006;18(10):641-6.

25. Mulimani PS. Evidence-based practice and the evidence pyramid: A21st century orthodontic odyssey. Am J Orthod Dentofacial Orthop. 2017;152(1):1-8. doi:10.1016/.ajodo.2017.03.020

26. Shaalan 00, Abou-Auf E,ElZoghby AF.Clinical evaluation of flowable resin composite versus conventional resin composite in carious and noncarious lesions: Systematic review and meta-analysis. J Conserv Dent. 2017;20(6):3805. doi:10.4103/JCD.JCD 226 17

27. CelikEU, AkaB, YilmazF.Six-month clinical evaluation of a self-adhesive flowable composite in noncarious cervical lesions. J Adhes Dent 2015;17(4):361-8. doi:10.3290/j.jad.a34556

28. Romero MF,HaddockFJ,Freites AG, BrackettWW, Brackett MG. Restorative technique selection in class iv direct composite restorations: a simplified method. Oper Dent. 2016;41(3):243-8. doi:10.2341/15-158-T

29. Ruschel VC, Martins MV, Bernardon JK, Maia HP.Color match between composite resin and tooth remnant in class iv restorations: a case series. Oper Dent. 2018;43(5):460-6. doi:10.2341/17-132-S

30. Baratieri LN, Ritter AV. Critical appraisal. To bevel or not in anterior composites. J Esthet Restor Dent. 2005;17(4):264-9. doi:10.1111/.j.1708-8240.2005.tb00126.x

31. Mackenzie L, Parmar D, Shortall AC, BurkeFJ. Direct anterior composites: a practical guide. Dent Update. 2013;40(4):297-9,301-2,305-8 passim.. doi:10.12968/denu.2013.40.4.297

32. Lopes IAD, Monteiro PJVC, Mendes JJB, Gonçalves JMR, Caldeira FJF. The effect of different finishing and polishing techniques on surface roughness and gloss of two nanocomposites. Saudi Dent J. 2018;30(3):197-207. doi:10.1016/j. sdentj.2018.04.003

33. Afroz S, Rathi S, Rajput G, Rahman SA. Dental esthetics and its impact on psycho-social well-being and dental self confidence: a campus based survey of north Indian university students. J Indian Prosthodont Soc. 2013;13(4):45560. doi:10.1007/s13191-012-0247-1 
34. Khurana R, Tredwin CJ, Weisbloom M, Moles DR. A clinical evaluation of the individual repeatability of three commercially available colour measuring devices. Br Dent J. 2007;203(12):675-80. doi:10.1038/bdj.2007.1108

35. Kielbassa AM, Beheim-Schwarzbach NJ, Neumann K, Nat R, Zantner C. In vitro comparison of visual and computer-aided pre-and post-tooth shade determination using various home bleaching procedures. J Prosthet Dent. 2009;101(2):92-100. doi:101016/S0022-3913(09)60001-9

36. Hickel R, Roulet J-F,Bayne S, Heintze SD, Mjoer IA, Peters M, et al. Recommendations for conducting controlled clinical studies of dental restorative materials. Science Committee Project 2/98--FDI World Dental Federation study design (PartI) and criteria for evaluation (Part II) of direct and indirect restorations including onlays and partial crowns [published correction appears in J Adhes Dent 2007 Dec;9(6):546]. J Adhes Dent. 2007;9 Suppl 1:121-47.

37. Marquillier T,Doméjean S, Le Clerc J,ChemlaF,Gritsch K, Maurin J-C, etal. The use of FDI criteria in clinical trials on direct dental restorations: A scoping review. J Dent. 2018;68:1-9. doi:10.1016/j.jdent.2017.10.007
38. Naeimi Akbar H, Moharamzadeh K, Wood DJ, Van Noort R. Relationship between Color and Translucency of Multishaded Dental Composite Resins. Int JDent.2012;2012:708032 doi:10.1155/2012/708032

39. Cadenaro M, Marchesi G, Antoniolli F,Davidson C, Dorigo EDS, Breschi L. Flowability of composites is no guarantee for contraction stress reduction. Dent Mater.2009;25(5):649-54. doi:10.1016/j.dental.2008.11.010

40. Aslam A, Ahmed B, Azad Aali, Ovais N, Nayyer M. Layers to a beautiful smile: composite resin stratification. Pakistan Oral Dent J. 2016;36(2):335-40.

41. Harris ED. Multi-Shade Composite Layering.J Cosmet Dent 2017;33(1).

42. Ragain J. A review of color science in dentistry: colorimetry and color space. $J$ Dent Oral Disord Ther.2016 Jan 26;4:1-5.

43. Chu SJ, Trushkowsky RD, Paravina RD. Dental color matching instruments and systems. Review of clinical and research aspects. JDent. 2010;38 Suppl 2:e2-e16. doi:10.1016/j.jdent2010.07.001

44. Moodley DS, Patel N, Moodley T, Ranchod H. Comparison of colour differences in visual versus spectrophotometric shade matching. South African Dent J. 2015;70(9):402-7.

\section{Ghada A Elzayat}

(Corresponding address)

304, Maxim Compound, North Teseen, 5th Settlement, Cairo, Egypt. 